\title{
Pengabdian Masyarakat: Pemanfaatan Nasi Bekas sebagai Pupuk dan Pestisida Tanaman Rumah di PKK Perumahan Jurang Mangu Indah, Bintaro
}

\author{
Nita Noriko ${ }^{*}$, Arief Lelono Arum, Hamisya Nurindriani, Crisnia, Cyndi Marcelina, Imam Rosadi, \\ Habib Pangeran, Dwi Atmi Narwati
}

Program Studi Biologi (Bioteknologi), Fakultas Sains dan Teknologi,

Universitas Al Azhar Indonesia, Jl. Sisingamangaraja, Jakarta 12110

*Penulis untuk korespondensi: nita_noriko@uai.ac.id

\begin{abstract}
Abstrak - Nasi bekas dan sisa makanan berbahan dasar karbohidrat lainnya merupakan jenis sampah organik yang dapat didaur ulang, tetapi biasanya hanya langsung dibuang atau diberikan ke unggas. Berdasarkan penelitian yang telah dilakukan bahan-bahan tersebut dapat dijadikan produk pupuk dan pestisida melalui fermentasi kapang yang disebut kapangisida. Kegiatan pengabdian masyarakat (abdimas) ini bertujuan untuk memperkenalkan pembuatan Kapangisida tersebut. Sasaran kegiatan ini adalah kelompok masyarakat dalam hal ini Pemberdayaan dan Kesejahteraan Keluarga (PKK) yang menaruh perhatian pada perawatan tanaman rumah yaitu PKK Perumahan Jurang Mangu Indah Bintaro. Hasil survei menunjukkan masyarakat di perumahan tersebut belum melakukan daur ulang nasi bekas menjadi kapangisida. Oleh karena itu, produk ini merupakan produk baru di masyarakat. Kelompok PKK ini juga bersedia untuk melakukan duplikasi proses pembuatan produk yang bermanfaat bagi tanaman.
\end{abstract}

Abstract - The used of rice and the waste of foods based on carbohydrate have not been recycled and are usually discarded or given directly to the poultry. Based on research that has been done, the waste can be converted to be fertilizer and pesticide products through the mold fermentation process. The product then called kapangisida. Our public service is aimed at introducing the making process of kapangisida. The target group, in this case is Empowerment and Family Welfare (PKK) that has concern at household plant treatment. We have selected PKK Perumahan Jurang Mangu
Indah that is situated in Bintaro. The result founds that the PKK has not recycled used rice and carbohydrate-based foods to be kapangisida. Therefore, this product is a new product in the community. The PKK also will do the duplication of kapangisida making process that beneficial to the plant.

Keywords - used rice, used carbohydrate-based food, mold, fertilizer, pestiside, plantation.

\section{PENDAHULUAN}

Sisa makanan berupa nasi dan yang berbahan $N_{\text {dasar karbohidrat jarang diperhatikan }}$ masyarakat untuk didaur ulang. Selama ini bahan tersebut biasanya diberikan sebagai tambahan pakan ternak terutama unggas. Penggunaan sebagai pakan ternak ini kurang efektif, karena tidak setiap rumah memiliki ternak unggas. Selain itu jumlah sisa nasi yang berbahan dasar karbohirat jumlahnya sedikit pada skala rumah tangga dan tidak dapat digunakan secara terus menerus.

Pendekatakan penggunaan nasi bekas yang lebih baik telah diteliti oleh Program Studi Biologi (Bioteknologi) pada tahun 2011. Prodi Biotek telah melakukan pengujian potensi nasi bekas sebagai pupuk bagi tanaman. Kapang digunakan sebagai agen pendegradasi yang sudah umum ditemukan pada pangan berbahan dasar karbohidrat bila dibiarkan dalam jangka waktu lama. Hasil degradasi kapang menjadikan nasi terurai sehingga nutrisinya mudah diserap oleh tumbuhan. Ekstrak kapang dapat berfungsi sebagai pestisida untuk melindungi tanaman dari hama. Kapang dapat dibuat menjadi starter kompos yang ramah 
lingkungan dan tidak berbahaya bagi manusia dan hewan [1].

Mengingat segi manfaat dan ketepatgunaan hasil penelitian, Prodi Biotek merasa perlu menyebarluaskan informasi agar dapat diaplikasikan di masyarakat. Pemanfaatan nasi bekas dan bahan sejenisnya dapat menimbulkan kebiasaan masyarakat untuk mendaur ulang sisa makanan sehingga mengurangi jumlah sampah rumah tangga. Tujuan dari kegiatan abdimas ini adalah memperkenalkan pembuatan kapangisida kepada kelompok masyarakat PKK yang menaruh perhatian pada perawatan tanaman rumah.

\section{TINJAUAN PUSTAKA}

Kapang (mold) merupakan cendawan renik yang mempunyai miselia dan massa spora yang jelas [2]. Kapang biasanya tumbuh pada permukaan makanan yang sudah basi atau terlalu lama tidak diolah. kapang terdiri atas miselium dan hifa serta memproduksi enzim sebagai biokatalis. Pertumbuhan kapang sangat mudah dikenali karena kenampakannya seperti serabut berwarna putih namun setelah terbentuk spora akan timbul bermacam-macam warna sesuai jenis kapang itu sendiri [3]. Berdasarkan morfologinya kapang merupakan mikroba dari jenis fungi yang multiseluler, yang berbentuk benang-benang dengan ukuran yang mikroskopik sampai dengan ukuran makroskopik. Struktur kapang berupa eukariotik yang terdiri dari miselium (kumpulan hifa) atau filament (kumpulan benang-benang). Kapang dapat dibedakan menjadi dua kelompok berdasarkan struktur hifa, yaitu hifa tidak bersekat atau nonseptat dan hifa bersekat atau septat. Setiap sel mempunyai satu inti atau lebih dengan dinding penyekat tidak bertutup rapat sehingga sitoplasma masih dapat bebas bergerak. Kapang tidak berseptat intinya tersebar di sepanjang septat [4]. Beberapa jenis kapang dapat memfermentasi bahan dasar sebagai substrat sehingga menjadi produk makanan tertentu (Tabel 1).

Pertumbuhan kapang dalam bahan makanan mudah sekali dilihat, yakni seperti kapas. Dalam pertumbuhannya kapang mula-mula berwarna putih, tetapi bila telah memproduksi spora maka akan terbentuk berbagai warna tergantung jenis kapang yang tumbuh. Sifat-sifat kapang baik penampakan mikroskopik maupun makroskopik digunakan untuk identifikasi dan klasifikasi [4].
Tabel 1. Pemanfaatan Kapang yang Sering Dijumpai [5]

\begin{tabular}{|c|c|c|}
\hline Produk & Bahan dasar & Jenis Kapang \\
\hline Tempe & Kedelai & $\begin{array}{l}\text { Rhizopus } \\
\text { Oligospora } \\
\text { Rhizopus Oryzae }\end{array}$ \\
\hline Oncom merah & $\begin{array}{l}\text { Bungkil kacang } \\
\text { tanah }\end{array}$ & Neurospora sitophia \\
\hline Oncom hitam & Ampas tahu & $\begin{array}{l}\text { Rhizopus } \\
\text { Oligospora } \\
\text { Rhizopus Oryzae }\end{array}$ \\
\hline $\begin{array}{l}\text { Kecap } \\
\text { Tauco }\end{array}$ & $\begin{array}{l}\text { Kedelai } \\
\text { Kedelai }\end{array}$ & $\begin{array}{l}\text { Aspergillus Oryzae } \\
\text { Aspergillus Orvzae }\end{array}$ \\
\hline $\begin{array}{l}\text { Tauco } \\
\text { Ragi tape }\end{array}$ & $\begin{array}{l}\text { Kedelai } \\
\text { Tepung beras }\end{array}$ & $\begin{array}{l}\text { Aspergillus Oryzae } \\
\text { Rhizopus, } \\
\text { Aspergillus, khamir }\end{array}$ \\
\hline Keju biru & Susu & $\begin{array}{l}\text { Penicililium } \\
\text { roqueforti }\end{array}$ \\
\hline Keju camemberti & Susu & P. camemberti \\
\hline
\end{tabular}

Kapang dapat hidup dalam keadaan sekitar yang tidak menguntungkan, bila dibandingkan dengan mikroba lainnya. Fisiologi kapang dipengaruhi beberapa aspek yaitu air, suhu, $\mathrm{pH}$, dan nutrisi [6]. Manfaat kapang pada tanaman diantaranya sebagai entomopatogen karena menghasilkan metabolit sekunder yang bersifat insektisida yaitu destruxin (cyclohexadepsipeptides). Selain itu, kapang jenis Mikoriza Vesikular Arbuscula (MVA) dapat meningkatkan pertumbuhan dan produksi tanaman pertanian seperti jagung dan kedelai [7].

\section{METODE PENELITIAN}

Sasaran kegiatan ini adalah PKK Perumahan Jurang Mangu Indah Bintaro yang menaruh perhatian pada perawatan tanaman rumah dengan jumlah 32 responden. Kegiatan abdimas dilakukan dengan cara presentasi materi, sosialisasi dengan media poster, demonstrasi cara pembuatan kapangisida, diskusi selama kegiatan dan evaluasi melalui pengisian kuesioner. Selain itu dilakukan pula pemberian produk pupuk dan pestisida dengan label kapangisida dalam kemasan botol kepada setiap peserta.

Cara pembuatan media kapang adalah mencampur nasi bekas atau sisa makanan berbahan dasar karbohidrat dengan air sebanyak volume bahan (1:1) yang dilanjutkan dengan pemanasan hingga menjadi bubur. Setelah dingin, bubur difermentasi dengan starter kemudian ditempatkan pada wadah plastik atau kantong plastik tertutup rapat. Starter kapang dibuat melalui pengenceran $5 \mathrm{ml}$ kapang yang berasal dari nasi yang dicampur dengan $50 \mathrm{ml}$ 
air. Pada hari kesepuluh, akan tampak hifa (benangbenang) pada permukaan bahan yang menandakan kapang dapat dipanen (Gambar 1.)

Ekstraksi kapang dilakukan dengan menambahkan air sebanyak 3 kali volume kapang kemudian dipanaskan sambil diaduk hingga kapang hancur. Pemanasan dilakukan hingga mendidih selama 30 menit. Setelah dingin filtrat disaring dan disimpan dalam botol (Gambar 2.). Cara pemakaiannya dengan menyemprotkan ke bagian daun dan batang tanaman. Untuk satu tanaman digunakan $10-50 \mathrm{~mL}$ ekstrak yang telah diencerkan 3 kali lipat.
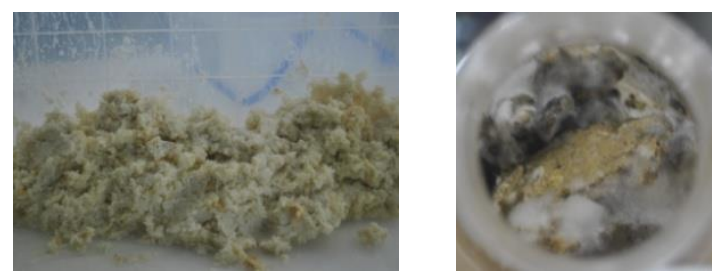

Gambar 1. Nasi Bekas dan Kapang

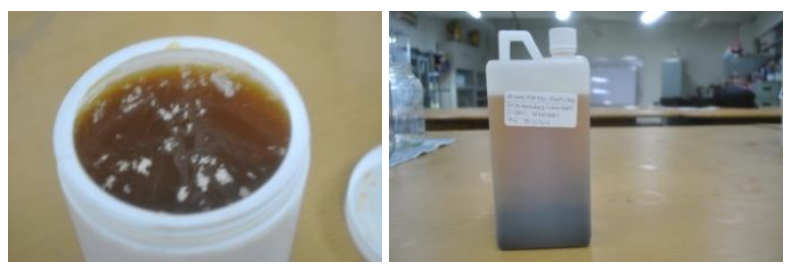

Gambar 2. Filtrat Kapang

Evaluasi dilakukan dengan pengisian kuesioner yang berisi 12 pertanyaan tertutup (Ya/Tidak), bertujuan untuk mendapatkan informasi seperti pada tabel 2 .

\section{HASIL DAN PEMBAHASAN}

Percobaan yang telah dilakukan oleh Prodi Biotek terhadap jangkrik menunjukkan 10 jangkrik mati setelah terpapar ekstrak kapang selama satu minggu. Hal ini sesuai dengan penelitian sebelumnya yang menyebutkan bahwa kapang entomopatogen dapat diformulasikan menjadi pestisida yang ramah lingkungan karena secara alamiah bersifat patogen pada serangga [8].
Tabel 2. Kuesioner Abdimas

\begin{tabular}{|c|c|}
\hline $\begin{array}{c}\text { Informasi yang } \\
\text { ingin didapat }\end{array}$ & Butir pertanyaan \\
\hline $\begin{array}{l}\text { Penggunaan } \\
\text { pupuk dan } \\
\text { pestisida serta } \\
\text { hasil yang } \\
\text { dirasakan } \\
\text { selama ini? }\end{array}$ & $\begin{array}{ll}\text { 1. } & \text { Apakah Ibu mempunyai } \\
\text { tanaman di rumah? } \\
\text { 2. } \\
\text { Apakah Ibu menggunakan } \\
\text { pupuk untuk merawat } \\
\text { tanaman tersebut? } \\
\text { 3. Jika jawaban nomor } 2 \text { "ya", } \\
\text { apakah hasilnya bagus? } \\
\text { 4. Apakah Ibu menggunakan } \\
\text { pestisida pada tanaman? } \\
\text { 5. Jika jawaban nomor } 4 \text { "ya", } \\
\text { apakah hasilnya bagus? }\end{array}$ \\
\hline $\begin{array}{l}\text { Kebiasaan } \\
\text { mendaur ulang } \\
\text { sampah dan sisa } \\
\text { makanan }\end{array}$ & 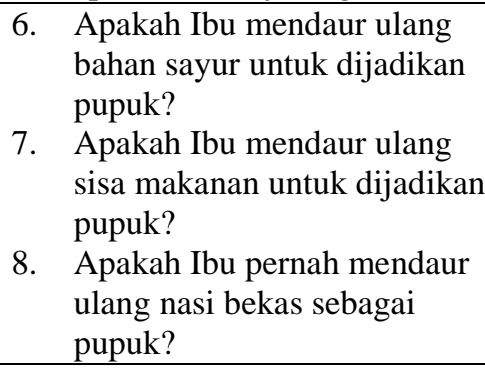 \\
\hline $\begin{array}{l}\text { Pengetahuan } \\
\text { tentang manfaat } \\
\text { kapang }\end{array}$ & $\begin{array}{l}\text { 9. Apakah Ibu tahu tentang } \\
\text { kapang pada nasi? } \\
\text { 10. Apakah Ibu tahu kapang } \\
\text { bermanfaat bagi tanaman? }\end{array}$ \\
\hline $\begin{array}{l}\text { Penambahan } \\
\text { pengetahuan } \\
\text { dan perubahan } \\
\text { sikap setelah } \\
\text { abdimas }\end{array}$ & $\begin{array}{l}\text { 11. Setelah mengikuti acara } \\
\text { abdimas, apakah menambah } \\
\text { pengetahuan Ibu dalam hal } \\
\text { merawat tanaman? } \\
\text { 12. Setelah mengikuti acara } \\
\text { abdimas, apakah Ibu mau } \\
\text { mendaur ulang nasi bekas } \\
\text { dengan fermentasi kapang } \\
\text { untuk dijadikan pupuk? }\end{array}$ \\
\hline
\end{tabular}

Secara alamiah, sejumlah kapang menghasilkan mikotoksin selama proses metabolismenya. Mikotoksikosis terjadi apabila hewan mengonsumsi toksin yang dihasilkan oleh kapang secara terus menerus dalam kurun waktu tertentu yang menyebabkan akumulasi toksin di dalam tubuh. toksin yang telah melewati ambang batas dapat menyebabkan gejala patologis hingga kematian [2].

Percobaan lebih lanjut, telah diujikan pada mawar, lantana, dan adenium yang memberikan hasil bahwa ekstrak kapang dapat memperbanyak jumlah daun dan mengingkatkan pertumbuhan tanaman sekaligus melindungi tanaman dari hama. Disebutkan bahwa pupuk kapang yang diekstrak dari nasi basi dapat meningkatkan kesuburan tanaman [9]. Produk pupuk dan pestisida ini kemudian diberi nama kapangisida yang artinya pestisida dan pupuk dari kapang. 
Selanjutnya Kapangisida disosialisasikan dalam bentuk pengabdian masyarakat yaitu pada Kelompok PKK Perumahan Jurang Mangu Indah Bintaro yang diketahui mempunyai minat yang besar terhadap tanaman. Hal ini dibuktikan dengan seluruh anggota PKK memiliki tanaman di rumah. Jenis tanaman yang ada meliputi tanaman bunga, buah, dan sayuran rumah. Anggota PKK cenderung menyukai tanaman buah dalam pot seperti rambutan.

Berdasarkan hasil kuesioner, tidak semua responden menggunakan pupuk dan pestisida untuk merawat tanaman di rumah. Sebanyak $15,63 \%$ tidak menggunakan pupuk tanaman; 63,50\% tidak menggunakan pestisida untuk perlindungan hama sedangkan sisanya tidak menggunakan ke duanya. Lebih lanjut lagi dari 84,38\% yang menggunakan pupuk; $43,75 \%$ mengatakan tidak puas dengan hasil pupuk yang dipakai, sedangkan untuk pengguna pestisida; $68,75 \%$ menyatakan tidak puas.

Hal tersebut menggambarkan bahwa PKK belum mendapatkan pupuk dan pestisida yang memberikan hasil yang optimal bagi tanaman mereka seperti yang ditunjukkan oleh rendahnya tingkat kepuasan terhadap hasil pupuk dan pestisida selama ini. Situasi tersebut dapat menjadi peluang yang baik bagi produk kapang yang berfungsi ganda sebagai pupuk dan pestisida untuk dikembangkan pada kelompok PKK. Akan tetapi, kebiasaan mendaur ulang sampah organik belum banyak dilakukan yaitu hanya $12,50 \%$ responden yang melakukan daur ulang sisa sayuran untuk dijadikan pupuk. Bahkan hanya ada 3,13\% yang mendaur ulang sisa makanan sebagai pupuk. Sosialisasi program daur ulang nasi sebagai pupuk bagi anggota PKK baru pertama kali dilaksanakan. Rendahnya kebiasaan daur ulang ini dapat ditingkatkan dengan sosialisasi kegiatan daur ulang, seperti Reuse, Reduce, Recycle (3R) untuk meningkatkan kesadaran lingkungan.

Sebanyak $31,25 \%$ responden telah mengetahui bahwa kapang dapat tumbuh pada nasi yang sudah lama dibiarkan. Namun hanya 9,38\% yang mengetahui manfaatnya pada tanaman. Secara keseluruhan $96,88 \%$ peserta yang hadir mengatakan materi yang disampaikan menambah pengetahuan tentang tanaman dan perawatannya dan bersedia untuk melakukan kegiatan daur ulang nasi bekas untuk dijadikan produk pupuk sekaligus pestisida.

\section{KESIMPULAN}

Kesimpulan yang dapat diambil dalam kegiatan abdimas ini adalah sebagai berikut:

1. Nasi bekas dan sisa makanan berbahan dasar karbohidrat berpotensi untuk digunakan sebagai produk pupuk dan pestisida.

2. Masyarakat belum banyak mengetahui dan memanfaatkan kapang pada nasi bekas sebagai pupuk dan pestisida.

3. Pembuatan produk pupuk dan pestisida tersebut dapat diduplikasi oleh masyarakat.

\section{UCAPAN TERIMA KASIH}

Terima kasih kepada Lembaga Penelitian dan Pengabdian Masyarakat (LP2M) Universitas Al Azhar Indonesia yang telah memberikan kesempatan untuk melakukan pengabdian masyarakat berbasis penelitian. Ucapan terimakasih juga kami sampaikan kepada ibu-ibu PKK di Perumahan Jurang Mangu Indah, Bintaro Tangerang.

\section{DAFTAR PUSTAKA}

[1] PDII-LIPI (Pusat Dokumentasi dan Informasi Ilmiah-Lembaga Ilmu Pengetahuan Indonesia). 2011. Memanfaatkan nasi bekas. http://www.pdii.lipi.go.id/read/2011/10/20/memanfa at-nasi-bekas.html (diakses pada 23 Juni 2012).

[2] Ahmad RZ. 2009. Cemaran kapang pada pakan dan pengendaliannya. Jurnal Litbang Pertanian 28: 15 22.

[3] Mahajati R. 2008. Efektivitas bungkil biji jarak pagar (Jatropha curcas L.) yang difermentasi berbagai jenis kapang sebagai pakan mencit (Mus musculus) [skripsi]. Institut Pertanian Bogor: Bogor.

[4] Anonim. 2008. Kapang. http://ml.scribd.com/doc/ 92592571/KAPANG (diakses pada 2 Mei 2011).

[5] Gandjar I, Sjamsuridzal W, Oetari A. 2006. Mikologi Dasar dan Terapan. Jakarta: Yayasan Obor Indonesia.

[6] Dewi A. 2011. Uji aktivitas antijamur ekstrak etanol rumput laut Sargassum ilicifolium (Turner) C. Agardh terhadap jamur Candida albicans [skripsi]. Universitas Sumatra Utara: Medan.

[7] Anonim. 2011. Isolasi Dan Karakterisasi Kapang Mikoriza Vesicular Arbuscular (MVA) pada Tanaman Jagung (Zea mays L.), dari http://wwwfandiinzaghi.blogspot.com/2010/07/isola si-dan-karakterisasi-kapang_25.html (diakses pada 28 Mei 2011) 
[8] Wahyudi P. 2008. Produksi mikoinsektisida dari propagul kapang Beauveria bassiana. Jurnal Matematika, Sains, dan Teknologi 2: 68-79.
[9] Kaleka N. 2011. Hijau dengan mol. Suara Merdeka 4 Oktober 2011

\section{LAMPIRAN}

Foto Kegiatan Abdimas di PKK PJMI Bintaro

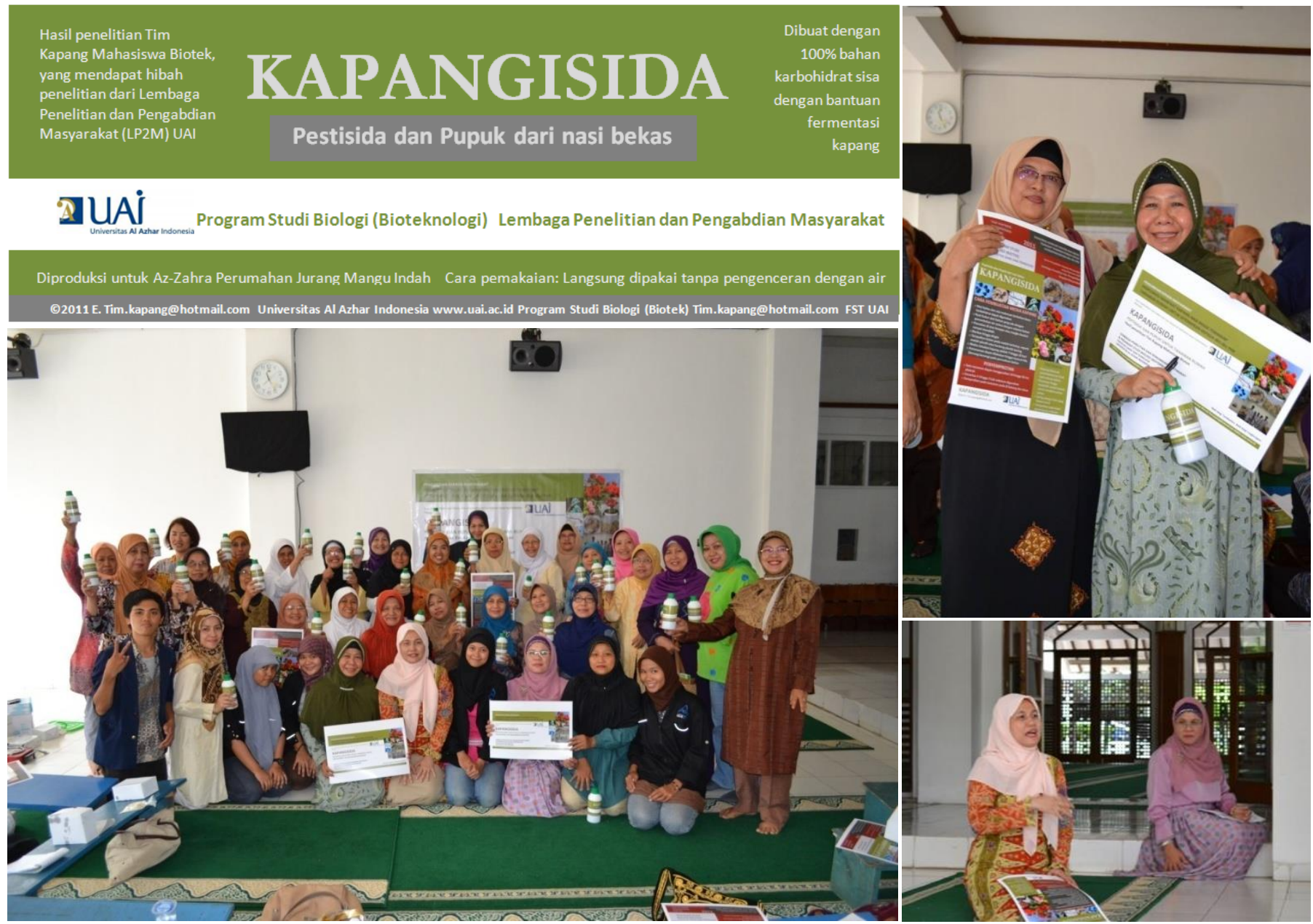

